\title{
Suç Korkusu:
}

\section{Tanım, Ölçüm ve Belirleyiciler}

\author{
Işıl ÇOKLAR ${ }^{1}$, Nevin SOLAK ${ }^{2}$
}

\begin{abstract}
$\ddot{O Z Z}$
Suç korkusu (fear of crime) bilişsel, duygusal ve davranışsal boyutları içeren karmaşık ve çok yönlü bir olgudur. Bu olgu, suça ve suçla ilişkili sembollere yönelik korku ya da kaygıyı içermektedir (Ferraro ve LaGrange, 1987). Son yıllarda, suç korkusu önemli bir sosyal sorun olarak görülmüştür. Böylelikle, söz konusu olgunun kavramsallaştırılması, ölçümü ve analizi disiplinler arası araştırmalar açısından ilgi çekmeye başlamıştır. Alanyazın incelendiğinde, suç korkusunun dinamiklerini anlayabilmek için incinebilirlik, mağduriyet, toplumsal düzensizlik ve sosyal bütünleşme modelleri olmak üzere dört kuramsal yaklaşımın ortaya konduğu görülmektedir. $\mathrm{Bu}$ makalenin amacı suç korkusuna ilişkin alanyazını incelemek ve gelecekte yapılabilecek araştırmalar için öneriler sunmaktır. Bu nedenle ilk olarak suç korkusunun tanımı, ölçümü ve belirleyici faktörleri konusunda kısa bir derleme sunulacak, ardından gelecek çalışmalarla ilgili bazı öneriler getirilecektir.
\end{abstract}

Anahtar sözcükler: suç korkusu, mağduriyet korkusu, mağduriyet, korku

Çoklar, I. ve Solak, N. (2017). Suç korkusu: Tanım, ölçüm ve belirleyiciler. Nesne, 5(10), 311-328.

\footnotetext{
${ }^{1}$ Yard.Doç. Dr., Okan Üniversitesi, Psikoloji Bölümü, isilcoklar(at)gmail.com

${ }^{2}$ Yard. Doç. Dr., TED Üniversitesi, Psikoloji Bölümü, nevin.solak(at)gmail.com

Yazar Notu: Her iki yazar bu çalışmaya eşit düzeyde katkı sağlamıştır.
} 


\title{
Fear of Crime:
}

\section{Definition, Measurement, and Predictors}

\begin{abstract}
Fear of crime is a complex and multifaceted phenomenon consisting of cognitive, affective, and behavioral dimensions. This concept is defined as a negative emotional reaction of dread or anxiety to crime or the symbols associated with crime (Ferraro \& LaGrange, 1987). In recent years, fear of crime has been recognized as an important social problem. Conceptualizing, measuring, and analyzing this concept, therefore, have received increased attention in interdisciplinary research. Research on fear of crime has addressed four specific theoretical approaches, namely the vulnerability, victimization, disorder, and social integration models. The aim of the current work was to examine the existing literature on fear of crime and make some suggestions for further research. First, we provided a short review of the definition, measurement, and determinants of fear of crime. Next, we made some suggestions for future research.
\end{abstract}

Keywords: fear of crime, fear of victimization, victimization, fear 
Suç korkusu, hem bireylerin yaşam kalitelerini hem de toplumu olumsuz etkileyen önemli bir sosyal sorundur (Franklin, Franklin ve Fearn, 2008; Liska, Sanchirico ve Reed, 1988; Taylor ve Hale, 1986). Suç korkusu, suça ve suçla ilişkili sembollere yönelik korku ya da kaygıy içeren olumsuz duygusal bir tepki olarak tanımlanır (Ferraro, 1995). Bu korku özellikle de şehir yaşamında yaygın olmakta ve kişinin yaşam biçimini etkilemektedir. Toplu taşıma araçlarını kullanmaktan, kalabalık yerlere gitmekten ve gece taksiye binmekten kaçınma, internet hesaplarının şifrelerini sık sık değiştirme, evde kimse olmadığı halde hırsızlık olasılığına karşı evde birileri varmış izlenimi yaratarak evin ışıklarını açık bırakma gibi davranışlar bu korkunun günlük hayattaki yansımalarıdır.

Geniş kapsamlı kültürler arası bir çalışma olan Uluslararası Suç Mağduru Anketi (Van Dijk, Van Kesteren ve Smit, 2007) ve 1994 yılı İngiliz Suç Anketi (Hough, 1995) sonuçları, suç korkusunun özellikle de gelişmekte olan ülkelerde yaygın olduğunu ortaya koymuştur. Örneğin, suç ve mağduriyet konularında bilgi sağlayan Uluslar Arası Suç Mağduru Anketi (Van Dijk ve ark., 2007), katılımcıların yaklaşık yüzde yirmi dokuzunun hırsızlığa uğrama korkusu yaşadıklarını göstermiştir. Çalışma bulgularına göre, İstanbul, Sao Paulo, Rio de Jenerio ve Maputo sakinleri hırsılzlk konusunda en endişeli katılımcılardır. Son yıllarda, global terörizmde artış yaşanmasıyla birlikte, terörist saldırıların kurbanı olma korkusunun da yaygınlaştığını ortaya koyan araştırma bulguları dikkati çekmektedir (örn., Cohen-Louck ve Ben-David, 2017; May, Herbert, Cline ve Nellis, 2011; Marshall, Bryant, Amsel, Suh, Cook ve Neria, 2007). Ayrıca, bilişim suçlarının kurbanı olma korkusu da günümüzde oldukça yaygınlaşmıştır (Henson, 2011). Suç korkusunun giderek artan bu yaygınlığı göz önüne alındığında, insanların suç hakkında niçin bu kadar korku duyduklarını, suç korkusuna nelerin etki ettiğini ve suç korkusunun sonuçlarını anlamak günden güne daha da önemli hale gelmektedir.

Korku duygusu insanların tehdit ve tehlike içeren bir duruma karşı gösterdikleri duygusal bir tepkidir (Öhman, 1993; Rachman, 1978). Bu duygunun ortaya çıkmasında söz konusu tehditle başetmek için kişinin kaynaklarının veya becerilerinin yetersiz algılanması önemli bir etkendir (Halperin, 2016). Korku duygusu insanların tehlikeli ortamlarda kendilerini korumalarına hizmet ettiğinden ötürü, belirli bir düzeye kadar varlığı hayatta kalmak için işlevsel kabul edilebilir. Bu nedenle suç korkusu, olası bir kayıptan kaçınmak için koruyucu davranışları tetiklediğinden her zaman olumsuz sonuçları olan bir duygu olarak değerlendirilmemelidir. Korku tehdidin düzeyi ve tipine uygun olduğunda işlevsel olabilmektedir (Clark, 2003). Ancak özellikle de suç mağduru olmanın algılanan olasıllğı, suç mağduru olmanın objektif olasılı̆̆ından yüksek olduğunda suç korkusu bir soruna dönüşebilmektedir (Doran ve Burgess, 2012). Suç korkusu sadece suçun yaygın olduğu mahalle sakinlerinde değil, aynı zamanda suçun daha az olduğu güvenli semtlerin sakinlerinde de görülmektedir (Furstenberg, 1971). 
Dolayısıyla, suç korkusunu yoğun şekilde yaşayanların, suç riski altında en çok bulunan kişiler olması gerekmemektedir.

Suç korkusu hem bireysel hem de toplumsal etkiler ortaya çıkaran, insanların düşünme, davranma ve karar alma süreçlerine tesir eden güçlü bir duygudur. Toplumsal şiddet ortamında yaşayan bireylerde korku günlük hayatın bir parçasıdır ve bireyler kendi ve yakınlarının hayatını ve kendi iç gruplarının varlığını tehdit altında algılama eğilimindedir (Halperin, 2016). Bireysel düzeyde suç korkusu hem psikolojik sağlık hem de fiziksel sağlık için olumsuz etkilere sahiptir (Doran ve Burgess, 2012). Özellikle psikolojik sağlık açısından bakıldığında, suç korkusu, öfke, engellenme, kayg1, çaresizlik, yabancılaşma, diğerlerine güvensizlik ve düşük yaşam doyumu ile ilişkilidir (Doran ve Burgess, 2012; Ferraro ve LaGrange, 2000). Bunların yanı sıra, suç korkusunun depresyon ya da travma gibi psikolojik rahatsılıklarla illişkisi de gözlenmiştir (Ferraro ve LaGrange, 2000; Spelman, 2004).

Davranışsal boyutta değerlendirildiğinde, korku kaçınma davranışını tetiklemektedir (Roseman, Wiest ve Swartz, 1994). Suç korkusu da kişilerin kendilerini güvende hissetmedikleri yer ve aktivitelerden kaçınmalarına yol açmaktadır (örn., Liska ve ark., 1988; Pantazis, 2000). Bu durum da sadece kişinin hayat tarzını etkilememekte, aynı zamanda belirli sosyal grupların hareket özgürlüğünü de kısıtlayarak gruplar arası hiyerarşilerin sürdürülmesini beraberinde getirmektedir. Örneğin, Keane (1998) suç korkusunun kadınların çevresel hareketliliğini kısıtladığını göstermiştir. Dolayısıyla, suç korkusundan kaynaklanan kaçınmacı davranışlar korkuyu azaltmaktan ziyade arttırabilmektedir (Liska ve ve ark., 1988). Ayrıca suç korkusu bireysel silahlanma gibi şiddet riski taşıyan davranışları pekiştime riski taşımaktadır. Warr (1992), diğerleri için korku duyduğunu ifade eden kişilerin önlem amaçlı silah sahibi olma oranlarının korku duyduğunu ifade etmeyenlerin yaklaşık üç katı olduğunu göstermiştir. Bu durumun özellikle de erkek katılımcılar arasında ortaya çıktığı görülmüştür. Korku duygusunu tetikleyen etkenlerden biri de tehdit alg1s1 ve belirsizliktir. Cinsiyetin yanı sira farkl1 grup aidiyetlerinin de suç korkusu ile arasındaki ilişki dikkat çekicidir. Örneğin, çok sayıda çalışma, korku ve tehdit algılarının önyargı, etnosentirizm ve politik muhafazakârlığı arttırdığını göstermiştir (Duckitt ve Fisher, 2003; Jost, Glaser, Kruglanski ve Sulloway, 2003). Dış grubun eylemlerinden korkma ve kaygı duyma (örn., terörist saldırı vb.) gruplar arası çatışmayı sürdürücü politikaların desteklenmesi ile ilişkilidir (Halperin, 2016). Dolayısıyla, kolektif etkileri açısından bakıldığında suç korkusu özellikle de gruplar arası eşitlik ve barış yönündeki sosyal değişimin önünde bir engeldir. Buradan hareketle, söz konusu kavramın yalnızca bireysel düzeyde değil grup içi ve gruplar arası süreçler açısından da oldukça önemli etkileri olduğunun farkına varılması, olası toplumsal düzenlemeler (sosyal poltika geliştirme çalışmaları, hukuksal düzenlemeler vb.) açısından da önem taşımaktadır. 
Geçtiğimiz son elli yıl içinde suç korkusu önemli bir sosyal sorun olarak kabul edilmeye başlanmış ve böylelikle söz konusu olguya ilişkin kavramsallaştırma ve olgunun altında yatan dinamiklerin ölçümü ve analizi disiplinler arası araştırmalar açısından ilgi çekici olmuştur. Psikologlar, sosyologlar, kriminologlar ve sosyal politika üreten kişiler bu konudaki alan yazına önemli katkılar sunmuşlardır. Bu makalenin amacı, suç korkusuna ilişkin alanyazını incelemek ve gelecekte yapılabilecek araştırmalar için önerilerde bulunmaktır. Bu nedenle ilk olarak suç korkusunun nasıl kavramsallaştırıldığı üzerinde durulacak, olguya ilişkin farklı kuramsal yaklaşımlar tanıtılacak, ardından suç korkusunu belirleyen etkenlerin neler olduğu gözden geçirilecektir. Suç korkusu alanındaki görgül çalışmalar derlenirken ölçme konusundaki sorunlar aktarılacak, son olarak da gelecekte yapılacak çalışmalarla ilgili öneriler sunulacaktır.

\section{Suç Korkusunun Tanımı}

Suç korkusu kavramındaki "korku" terimi, özgül dişsal ve nesnel bir tehdit karşısında verilen otomatik bir tepkiden çok kaygı ve endişeler için kullanılmaktadır (Fisher, Allan ve Allan, 2004; Hough, 1995). Suç korkusu, yukarıda da bahsedildiği gibi, genellikle "suça ya da suçla ilişkili sembollere yönelik olumsuz bir duygusal tepki” olarak tanımlanmaktadır (Ferraro ve LaGrange, 1987, s.72). Benzer biçimde, Covington ve Taylor (1991) da suç korkusunun "olası şiddet içerikli bir suç ve fiziksel zarara yönelik duygusal tepki” olduğunu ileri sürmüşlerdir.

Alanyazın incelendiğinde, suç korkusu konusundaki çalışmaların arttığı görülmekle birlikte, araştırmacıların suç korkusunun işevuruk tanımı konusunda uzlaşmaya varamadıkları dikkati çekmektedir (Ferraro ve LaGrange, 1987; Warr, 1984). Örneğin, Ferraro ve LeGrange (1987) algılanan risk ile suç korkusunun çoğu kez aynı şeymiş gibi değerlendirildiğini ve bunun suç korkusu araştırmalarındaki ölçme sorunlarının da temelini oluşturduğunu ileri sürmüştür. Buna göre, mağdur olma konusunda algılanan risk ve suç korkusu birbiriyle ilişkili ancak farklı kavramlardır. Korku duygusal bir tepkiyi yansıtırken, risk ise bir şeyin olma olasılığına yönelik bilişsel bir değerlendirmeye işaret etmektedir. Suç korkusunun tanımı konusundaki bir diğer tartışma da özgüllük üzerinedir. İnsanlar en çok hırsızlık ve tecavüz gibi suçlar konusunda endişe duymaktadır (örn., Hough, 1995). Bu nedenle de suç korkusunun "genel” bir kavram mı yoksa "özgül” (suç türüne özgü) bir kavram mı olduğu konusunun tartışılması gerektiği öne sürülmüştür (Ferraro ve LaGranger, 1987).

Bunlara ek olarak, alanyazın kişinin kendisi için duyduğu suç korkusuna özel bir dikkat göstermekle birlikte (Rader, 2004), son yıllarda kişinin kendisi için duyduğu korku ve diğerleri için duyduğu korku ayrı değişkenler olarak çalışılmaya 
başlanmıştır (örn., Warr, 1992; Warr ve Ellison, 2000). Buna göre, Fishman ve Mesch (1996) suç korkusunun dört boyutu içeren çok boyutlu doğasına işaret etmiştir. Bunlar, kişisel mağduriyet korkusu, ailenin mağduriyetine ilişkin korku, şiddet içerikli suç korkusu ve beyaz yakalı suç korkusudur. Warr ve Ellison (2000), "özgeci korku"nun (yakınlar için duyulan korku) kişinin kendisi için duyduğu korkdan daha yoğun olduğunu bulmuşlardır.

Özetle, suç korkusunun çok sayıda kavramsallaştırması bulunmaktadır ve söz konusu kavramın işe vuruk tanımı konusunda tartışmalar sürmektedir. Alan yazın incelendiğinde ve kavramın disiplinler arası doğası göz önüne alındığında, standart bir tanım yapmak için farklı disiplinlerin bilgisini ve farklı yaklaşımları bir araya getirmek gerektiği dikkati çekmektedir.

\section{Suç Korkusunun Ölçümü}

Suç korkusuna ilişkin kavramsallaştırmanın yanı sıra kavramın ölçümü konusunda da bir tutarlılık bulunmamaktadır (Franklin ve ark., 2008). Alanyazında suç korkusunu ölçmeye yönelik pek çok farklı girişime rastlanmaktadır. Geçmişte yapılan araştırmalarda suç korkusu genel bir yapı olarak ele alınmış, geniş çaplı anket çalışmaları kapsamında ölçülmüş ve bu genel formu ölçülmeye çalışılırken kullanılan tipik soru "Karanlıkta yaşadığınız bölgede yürürken kendinizi ne kadar güvende hissediyorsunuz?" olmuştur (örn; Uluslar Arası Suç Anketi, Van Dijk, Van Kesteren ve Smit, 2007). Bu soru türü araştırmacılarca eleştirilmiştir. Örneğin, Ferraro ve LaGrange (1987) bu tür ölçümlerin mağdur olma riskine ilişkin sadece bilişsel değerlendirmeleri kapsadığını, bu nedenle de tek bir sorunun yeterli olmadığını belirtmiştir. Anketlerde kullanılan bir diğer popüler soru "Herhangi bir suçun mağduru olma konusunda ne kadar endişe duymaktasınız?"dır (Ditton ve Gilchrist, 1997; Farrall, Bannister, Ditton, \& Gilchrist, 1997). Ancak bu soru da çok genel bir nitelik taşımaktadır, korkudan ziyade sadece kaygı duygusuna odaklanmaktadır ve özgül suç türlerini kapsamamaktadır.

Alanyazında karşılaştığımız en ilgi çekici ölçek "Suç Korkusu Ölçeğì"dir (Phelan, Sanchez ve Broccoli, 2010). Araştırmacılar, yirmi sekiz maddelik bu ölçeği katılımcıların suç korkularını değerlendirmek amacıyla kullanmışlardır. Araştırmacılar ölçeğin Cronbach Alfa güvenirlik katsayısının çok yüksek olduğunu bildirmiş olsalar da, söz konusu ölçme aracında suç korkusu kavramının bilişsel, duygusal ve davranışsal bileşenleri konusunda herhangi bir ayrım yapmamışlar, tek boyutlu bir değerlendirme ortaya koymuşlardır. Ayrıca, ölçekte daha çok davranışsal bileşene ilişkin maddelerin yer aldığı (örn; "Gece geç vakitte eve döneceğim zaman arkadaşlarımdan bana arabama/metroya kadar eşlik etmelerini isterim”) gözlenmiştir. Buna karşın duygusal bileşenle ilgili çok az sayıda maddeye yer 
verilmiştir (örn; "Fiziksel olarak saldırıya uğramaktan korkuyorum"). Alanyazın incelemesi sonucunda suç korkusu ölçeklerinin geliştirilmesine ihtiyaç olduğu görülmektedir.

Son dönem araştırmalar ise suç korkusunu, duygusal korku ve mağdur edilme konusunda algılanan riski birbirinden ayırt ederek ölçmektedir (Farrall ve ark., 1997; Franklin ve ark., 2008; Williams ve ark., 2000). Bu araştırmalarda ayrıca suç korkusunun davranışsal boyutuna ilişkin sorular da yer almaktadır (örn; sprey taşımak, hırsızlık için alarm taktırmak). Her ne kadar çoğu çalışma suç korkusu ile ilgili genel sorular kullansa da bazı araştırmacılar cinsel saldırı, dolandırıcılık, hırsızlık gibi belirli suçlara ilişskin korkuyu ölçme girişiminde bulunmuşlardır (Dobbs, Waid ve Shelley, 2009; Keane, 1992; Williams ve ark., 2000).

Ölçmedeki bir diğer sorun kişisel güvenliğe ilişkin korku ile kişinin yakınlarının mağduriyeti konusunda duyduğu "özgeci korku" arasındaki ayrımın eksikliğidir (Warr, 1992; Warr ve Ellison, 2000). Daha önce de bahsedildiği üzere, kendini potansiyel mağdur olarak görmese de yakınlarını potansiyel mağdur olarak gördüklerinden dolaylı insanlar suç korkusu yaşayabilmektedir. $\mathrm{Bu}$ da suç korkusunun ölçülmesinde kişilerin kendilerine yönelik risk algılarının yeterli veriyi sağlamayacağını düşündürmektedir.

Bunların yanı sıra, suç korkusu araştırmalarına yöneltilen başka eleştiriler de bulunmaktadır. Eleştiriler, suç korkusu anketlerinin durumsal etkenleri (zaman ve mekan gibi), olayların kişiler için anlamlarını ve bellek yanlılıklarını dikkate almadıkları yönündedir (Farrall ve ark., 1997). Suç korkusu ile ilgili diğer faktörler arasındaki nedensel ilişkileri ortaya çıkarmak için deneysel ve boylamsal çalışmalara da gereksinim vardır. Nitekim 90'l yıllardan itibaren hem laboratuar hem de alan deneyleri ile yürütülen çalışmalar alan yazına katkı sunmuştur (Addington, 2003; Ratcliffe, Taniguchi, Virij ve Winkel, 1991). Nicel çalışmalara ek olarak, insanların suç korkusu deneyimlerini incelemek üzere sosyal bağlam konusunda daha hassas olan nitel ve etnografik çalışmalar da yürütülmüştür (örn., Pain, 2000). Hem nitel hem de etnografik çalışmalar suç korkusunun doğası ve dinamikleri konusunda çok yönlü kuramsal destek sağlamışlardır.

Sonuç olarak, özellikle suç korkusunun zayıf kavramsallaştırması nedeniyle yöntemsel bazı tartışmalar ortaya çıkmıştır. Alanyazın incelendiğinde betimsel çalı̧̧maların kişisel suç korkusunu değerlendirmek üzere genellikle tek bir soru ya da ölçek olmayan bir soru grubu kullandıkları görülmektedir. Üstelik kullanılan ölçümlerin çoğunun psikometrik özelliklerinde sorunlar bulunmaktadır. Bunun yanı sıra, söz konusu ölçümlerin suç korkusunun olası boyutlarını yakalayamadıkları ve bağlamsal faktörlerin etkilerini de görmezden geldikleri görülmektedir. 


\section{Suç Korkusu Modelleri}

Alanyazındaki bazı çalışmaların sosyal, politik ve sosyodemografik bağlamı yeterince dikkate almayarak suç korkusunun dinamiklerini birey düzeyinde incelemesi önemli bir tartışma konusu olarak ele alınmıştır (örn., Reese, 2009). Bireysel, sosyal ve sistem faktörlerinin etkileşimsel olarak suç korkusu kavramını nasıl etkilediklerini incelemek çok daha geniş kapsamlı bir bakış açısı oluşturabilir. Alanyazın incelendiğinde, suç korkusunun dinamiklerini anlayabilmek için çeşitli modellerin formüle edildiği görülmüştür. $\mathrm{Bu}$ modeller arasında bireysel düzeyde incinebilirlik (vulnerability), mağduriyet (victimization), düzensizlik (disorder) ve sosyal bütünleşme (social integration) öne çıkmaktadır (Farrall, Gray ve Jackson, 2007; Franklin ve ark., 2008; Franklin ve Franklin, 2009; Taylor ve Hale, 1986). Mağduriyet ve incinebilirlik modelleri suç korkusunu birey düzeyinde analiz ederken, düzensizlik ve sosyal bütünleşme modelleri makro düzeyde analizler yapmakta ve yerel çevrenin özelliklerini dikkate alan savlar ortaya koymaktadır. Buradan hareketle, incinebilirlik ve mağduriyet modellerinin psikolojik modeller oldukları, düzensizlik ve sosyal bütünleşme modellerinin ise sosyoloji ve çevre psikolojisine daha yakın durdukları ileri sürülebilir.

İncinebilirlik modeline gore, kişisel incinebilirlik algısı bireylerin suç korkusunu etkiler (Franklin ve ark., 2008; Taylor ve Hale, 1986). Araştırmacılar fiziksel, sosyal ve/veya ekonomik dirençleri yoluyla kendilerini koruma konusunda daha yetersiz hisseden kişilerin kendini koruma kapasitesine sahip olduğunu hissedenlerle karşılaştırıldığında daha yüksek düzeyde suç korkusu yaşadıklarını belirtmektedir (Hale, 1996). İncinebilirlik modeli, kişinin kendisini fiziksel ve sosyal olarak bir suç mağduru olmaktan koruyamayacağını hissetmesinin algılanan mağduriyet riskini arttırdığını ileri sürmektedir. Fiziksel incinebilirlik algılanan fiziksel saldırı riski ile ilişkilidir ve kısıtlanan hareketlilik ya da muhtemel bir saldırıya karşı koyma yetersizliği ile nitelenir. Bu sav doğrultusunda, kadınların ve yaşlı insanların erkeklerle ve genç insanlarla karşılaştırıldıklarında fiziksel olarak daha incinebilir oldukları ileri sürülebilir. Nitekim çok sayıda çalışma kadınların (Dobbs ve ark., 2009; Fishman ve Mesch, 1996; Liska ve ark., 1988 ; Reese, 2009; Warr, 1984) ve yaşlı bireylerin (Hough, 1995; Liska ve ark., 1988; Warr, 1984) daha yüksek düzeyde suç korkusu bildirdiklerini ortaya koymuştur. Buna karşın, erkeklerin "korkusuz" ve "incinmez" erkek kalıpyargıları nedeniyle suç korkularını bildirmeye isteksiz olabilecekleri de tartışılmaktadır (Pain, 2000). Sonuç olarak, maddi ve sosyal kaynakları yetersiz olan ya da içinde bulundukları topluluk ve sosyal ağlarda kaygı uyandırıcı durumlarla (örn; bireysel ya da kurumsallaşmış 1rkçılık) baş etmeleri konusunda yeterli desteğe sahip olmayan kişilerin daha yüksek düzeyde bir sosyal incinebilirliğe sahip olması olasıdır (Franklin ve ark, 2008). Bu bakış açısından hareketle yürütülen çok sayıda araştırma, ırksal ya da etnik 
azınlıkların, yoksulluk içinde yaşayan kişilerin ve daha düşük eğitim düzeyine sahip kişilerin beyaz, varlıklı ve iyi eğitimli kişilerden daha yüksek düzeyde suç korkusu bildirdiklerini ortaya koymuştur (Baumer, 1978; Covington ve Taylor, 1991; Erskine, 1974; Furstenberg, 1971; Jaycox, 1978; Pantazis, 2000; Taylor ve Hale, 1986). Yine başka birtakım araştırmalar, düşük eğitim düzeyinin, düşük gelir düzeyinin, işsiz olmanın, bir etnik azınlık grubunun üyesi olmanın daha yüksek düzeyde suç korkusu sergilemekle ilişkili olduğunu göstermiştir (Eitle ve Taylor, 2008; Karakus ve ark., 2010; Parker, 1988; Reese, 2009). Pain (2000) gelecekte yapılacak araştırmalarda evsizler, seks işçileri, engelli bireyler, geyler ve lezbiyenler gibi dezavantajlı grupların üyelerinde de suç korkusunun incelenmesi gerektiğini ileri sürmüştür.

Diğer taraftan, avantajlı ve dezavantajlı grupların üyelerinin farklı nedenlerle suç korkusu sergiledikleri vurgulanmalıdır. Avantajlı gruplar için azınlıkları bir tehlike olarak etiketlemek gruplar arasındaki sınırları genişletmekte ve avantajlı grupların toplum üzerindeki kontrolünü arttırmaktadır (Pain, 2000). Buradan hareketle, suç korkusunun dezavantajlı gruplara yönelik önyargıları ve ayrımcılığı meşrulaştırdığı ileri sürülebilir. Dolayısıyla, suç korkusunun yalnızca bireysel bir olgu değil gruplar arası ilişkiler açısından da önemli bir olgu olduğu açıktır.

Suçun farklı türleri konusundaki korkuları incelemiş olan Hough (1995) erkeklerle karşılaştırıldıklarında, kadınların ve genç insanlarla karşılaş̧ırıldıklarında, daha yaşlı bireylerin dışarıda yalnız olduklarında daha az güvende hissettiklerini ve gasp edilme konusunda daha fazla endişelendiklerini ortaya koymuştur. Ancak hırsızlık konusundaki cinsiyet farklılıkları daha az bulunmuş, hatta arabadan eşya çalınması konusunda ise tersine bir örüntü ortaya çıkmıştır. Daha yaşlı insanların hırsılık, arabadan hırsızlık ve tecavüz konusunda daha az korku bildirdikleri bulunmuştur. $\mathrm{Bu}$ bulgular dikkate alındığında, yalnızca demografik özelliklerin değil, bu özelliklerin suç türü ile etkileşiminin de suç korkusunun anlaşılmasında önemli olduğu görülmektedir.

İkinci model olan mağduriyet hipotezi ise doğrudan yaşanmış mağduriyet deneyiminin suç korkusunu arttıracağını ileri sürer. Mağduriyet modeline farklı araştırmalarca görgül destek sağlanmıştır (Eitle ve Taylor, 2008; Karakus ve ark., 2010; Reese, 2009). Bu görgül kanttlardan biri de ülkemizde yürütülen ve geçmiş mağduriyetin suç korkusu ile olumlu ilişkisini gösteren bir araştırma tarafından ortaya konmuştur (Karakus ve ark., 2010). Bununla birlikte, bazı araştırma bulguları mağduriyet modelini desteklememektedir (örn., Fishman ve Mesch, 1996; Gibson, Zhao, Lovrich ve Gafney, 2002; McGarrell ve ark., 1997). 
Üçüncü model yaşanılan çevredeki toplumsal ve fiziksel karmaşanın suç korkusuna neden olduğunu ileri süren düzensizlik modelidir (Franklin ve ark,, 2008; Taylor Hale, 1986) Nüfus istikrarsızlı̆̆ı, rksal heterojenlik, şehirleşme ve endüstrileşme mahallelerde düzensizlik sorunlarını ve suç korkusunu etkilemektedir. Nezaketsiz mahalle sakinleri, çeteler, kamusal alanda içki içenler, evsizler ve dilenciler, tahrip edilmiş mülkler, terk edilmiş evler düzensiz ortamların göstergeleridirler. (Covington ve Taylor, 1991; Franklin ve Franklin, 2009; McGarrell ve ark., 1997). Franklin ve arkadaşları (2008) düzensizlik modelinin suç korkusunun bilişsel ve duygusal bileşenlerini incinebilirlik ve sosyal bütünleşme modellerinden daha iyi açıkladığını ortaya koymuşlardır. Düzensizlik modeli, Türkiye'deki katılımcılarla yürütülen araştırma sonuçları ile de doğrulanmış, sosyal çevredeki (özel mahalledeki) düzensizliğin katılımcıların suç korkusu ile ilişkili olduğuna dikkat çekilmiştir (Karakus, McGarell ve Basibuyuk, 2010).

Diğer bir model olan sosyal bütünleşme modeli (Franklin ve ark., 2008) sosyal bütünleşmeye ve yerel ortamlara ait olma hissine vurgu yapmaktadır. Diğer bir deyişle, yer bağl1lığ sosyal bütünleşme modeli için önemli bir etmendir. Modele göre, yerel ortamlarla/mekanlarla kurulan özdeşimin yüksekliği ya da daha güçlü sosyal bağlar kurulması daha düşük düzeyde suç korkusu sergilenmesi ile ilişkilidir. Araştırmalar sosyal etkileşim modeli için de destekleyici bulgular elde etmişlerdir. Örneğin, mahalle ile toplumsal olarak bütünleşme (Franklin ve ark, 2008) ve mahalleye bağlanma (Oh ve Kim, 2008) algılanan mağduriyet riskini azaltmaktadır. Gibson ve arkadaşları (2002) yüksek düzeyde sosyal bütünleşmenin daha yüksek düzeyde toplulukçu-yeterlik algısı üzerinden işlev gördüğünü bunun da daha düşük düzeyde suç korkusunu yordadığını bulmuşlardır. Ek olarak, suç mağduru olma endişesi ile sosyal bütünleşme arasında cinsiyet farklılı̆̆ 1 olduğu bulunmuş, sosyal bütünleşmenin erkeklerde değil ancak kadınlarda suç korkusunu azalttığı ortaya konulmuştur (Franklin ve Franklin, 2009). Bu bulgular cinsiyet gruplarının farklı sosyalleşmeleri temelinde tartışılmıştır. Araştırmacılara göre kadınlar kendilerini diğerleri ile ilişkili olarak tanımlaya daha fazla eğilimlidirler, sosyal destek ve sosyal bütünleşme onlar için erkekler için olduğundan daha büyük önem taşır. Sosyal bütünleşme modeli, Türkiye'de yürütülen çalışma bulguları ile de desteklenmiş olup mahalle ile bütünleşme arttıkça katılımcıların suç korkularının azaldığı ortaya konmuştur (Karakus ve ark., 2010).

Tüm modeller bir arada değerlendirildiklerinde aynı olgunun farklı yönlerini açıklama girişiminde oldukları görülmektedir. $\mathrm{Bu}$ nedenle bu modeller birbirlerini tamamlayan modeller olarak değerlendirilmelidirler. $\mathrm{Bu}$ modellerin dışında, cezaevi firarları konusunda sunulan televizyon haberlerine maruz kalma (Fisher, ve ark., 2004), korumacı cinsiyetçilik (Phelan ve ark., 2010) ve kanunların yürütülmesinden memnuniyet (Karakus ve ark., 2010) gibi suç korkusu algıları ile 
ilişkili pek çok etmen bulunmaktadır. Dolayısıyla gelecekte yürütülecek araştırmalarda hem kuramsal modellerin sınanması hem de araştırmaların yürütüldüğü örneklem gruplarına özgü farklı etkenleri ve bağlamsal farklılıkları ortaya çıkaracak değişkenlerin incelenmesi önerilebilir. Bu durumda nicel araştırma verilerinin yanı sıra nitel araştırma verilerinin de zenginleştirici bulgular ortaya çıkaracă̆ 1 göz ardı edilmemelidir.

\section{Sonuç ve Öneriler}

Suç korkusu disiplinler arası perspektiften ele alınmış olan çok boyutlu bir kavramdır. Yapılan çok sayıda çalışmaya karşın, suç korkusunun tanımı ve ölçümü konusunda tartışmalar sürmektedir. Suç korkusu psikolojik bir durum ve deneyim olmakla birlikte, psikoloji alanından gelen araştırmacıların bu konuya duydukları ilgi sosyologlar ve kriminologların gerisinde kalmıştır. Bu nedenle, özellikle de kavramın ölçümü konusundaki sorun henüz çözülmüş değildir. Tek maddelik ölçümler yerine yeterli psikometrik niteliklere sahip çok boyutlu güvenilir ve geçerli ölçeklerin geliştirilmesine ihtiyaç vardır. Dahası diğer disiplinlerle karşılaştıııldığında psikologların daha karmaşık istatistiksel yöntemleri kullanarak farklı yapıların suç korkusu ile arasındaki ilişkiyi ortaya koyması mümkündür. Ancak maalesef suç korkusu alanyazınında genellikle yalnızca sosyo-demografik değişkenlerin etkilerinin incelendiği birbirine benzer çalışmalara rastlanmaktadır. $\mathrm{Bu}$ çalışmaların çoğunda suç kokusu birkaç madde ile ölçülmeye çalışılmış ve bulgular da betimleyici istatistiklerin sunumuyla sınırlı kalmıştır. Elbette bu çalışmalar olgunun ortaya konması bakımından büyük önem taşımaktadır, ancak olgunun daha ayrıntılı biçimde anlaşılması ve pratik doğurguların ortaya çıkarılması bakımından çok boyutlu yeni çalışmalara ihtiyaç vardır. $\mathrm{Bu}$ nedenle psikoloji alanında yürütülecek araştrmalar sonucunda suç korkusu kavramının işevuruk tanımının yapılması, yeni ölçme araçlarının geliştirilmesi ve olgunun çok boyutlu doğasının ortaya konması konusunda somut katkılar elde edilebilir.

Alanyazın incelendiğinde sosyal psikolojik yapılar ile suç korkusu arasındaki ilişkiye dair yeterli araştırma bulunmadığı dikkati çekmektedir. Yetkecilik, algılanan kontrol, dindarlık, adil dünya inanc1, muhafazakârlık, ideoloji, sosyal baskınlık yönelimi, sistemi meşrulaştırma eğilimi, vatanseverlik gibi çok sayıda sosyal psikolojik kavramın suç korkusu ile ilişkili olabileceği göz önünde bulundurulduğunda, konuyla ilgili bireysel ve gruplar arası düzeyde ortaya çıan farklılıkları anlamada sosyal psikolojinin büyük katkılar sunabileceği düşünülmektedir. 
Bir diğer önemli konu da suç korkusunun analiz düzeyidir. Suç korkusu yalnızca kişisel değil kişiler arası süreçleri ve grup süreçlerini de etkilemektedir. Alanyazın suç korkusunu çoğunlukla bireysel bir olgu olarak ele almıştır. Oysaki, suç korkusu yakın ilişkileri (romantik ilişkiler, arkadaşlık, ebeveyn çocuk ilişkisi) etkileyen önemli bir olgudur. Üstelik suç korkusu başat gruplar ile dezavantajlı gruplar arasındaki ilişkiler bakımından da büyük önem taşımaktadır. Bu konuda yanıt aranabilecek sorulardan bazıları şu biçimde sıralanabilir: Suç korkusu gruplar arasındaki eşitsizliği nasıl meşrulaştırmaktadır? Suç korkusu dezavantajlı gruplarda grupiçi küçümsemeyi ve dışgrup yanlılığını arttırmakta mıdır? Tersine, suç korkusu avantajlı gruplar açısından içgrup sevgisini yükseltirken dış gruba yönelik nefreti arttırmakta mıdır? Bir diğer konu da çoklu sosyal kimliklerle ilgilidir. Alanyazında insanların çoklu sosyal kimlikleri arasındaki etkileşim suç korkusunun belirleyicisi olarak incelenmemiştir. Oysaki, toplumsal cinsiyet, etnik köken, ait olunan sosyoekonomik sınıf gibi farklı kimlik yapılarının sadece bireysel olarak değil aynı zamanda bunların birbiriyle etkileşimlerinin de suç korkusu konusundaki yanıtları etkileyebileceği dikkate alınmalıdır. Sosyal politikalara ilişkin tutumlarla suç korkusu arasındaki ilişkiler incelenmesi gereken bir diğer boyuttur. Özellikle kitle iletişim araçları sosyal politikalara yönelik tutumları etkilemede büyük rol oynamaktadır. Çünkü suçla ilgili haberlerin sunulma şekli ve süresi bireylerin suç korkusunu aynı zamanda da suça ilişkin tutumlarını biçimlendirebilmektedir.

Suç korkusu ile baş etme stilleri ve bu korkunun nasıl düzenlendiği gelecekte üzerinde durulması gereken bir diğer araştırma konusu olabilir. Geçmiş çalışmalar daha çok kaçınma gibi davranışsal bileşenlere odaklanmıştır. Fakat insanların baş etme süreçlerinde kullandıkları bilişsel stratejiler de bulunmaktadır. Örneğin, bilişsel yeniden değerlendirme, gerçekçi olmayan iyimserlik, olumsuz düşünceleri bastırma suç korkusu ile baş ederken kullanılan stratejilere örnek oluşturabilir. Gelecekteki çalışmalar suç korkusu ile baş etmede kullanılan davranışsal ve bilişsel stratejileri ve bunların iyi oluşla ilişkilerini de ortaya koyabilir.

Suç korkusunun türleri de bir diğer önemli araştırma konusu olarak dikkate alınmalıdır. Geçmiş çalışmalar genellikle hırsızlık, saldırı gibi klasik suç türleri üzerinde odaklanmaktadır. Oysaki gelişen teknoloji ile birlikte internet ortamında kimliğin çalınması, kişisel verilerin, mahrem bilgilerin, görsellerin kişinin izni olmadan paylaşılması gibi sanal birtakım suçlar ortaya çıkmıştır. Bu görece yeni suç türlerinin insanlarda yarattığı korku da önemli bir çalışma alanı oluşturacak niteliktedir. Sosyo-ekonomik konumu ya da eğitim-iş durumu nedeniyle teknolojik gelişmelerle daha fazla iç içe yaşayan kişilerin bu konulardaki duyarlılıklarının daha yüksek olması beklenebilir. Bu kişilerin yaşadıkları korkunun düzeyleri ve baş etme stratejileri de çalışılması gereken konular arasındadır. 
Gelecekte yürütülecek araştırmalar, suç korkusunda kültürün etkilerini de incelemelidir. Alanyazında kültürler arası çok sayıda çalışma bulunmakla birlikte genel anlamda suç korkusunu yordayan değişkenler olarak bireyci-kültürcü örüntülerin, farklı kültürlerdeki değerler ve toplumsallaşma süreçlerinin rolünü ortaya koyan özgül çalışmalar bulunmamaktadır. Suç korkusu konusunda çalışmalar yürüten araştırmacılar çevre psikolojisi araştırmacılarıyla da işbirliği yapmalıdırlar. Özellikle yer kimliği, yer bağlılığı, içinde yaşanan çevrenin bilişsel temsilleri araştırmacıların insan-çevre ilişkilerinin dinamiklerinin suç korkusunu yordamadaki rolü üzerine fikir sahibi olmalarını sağlayacaktır.

Suç korkusu nasıl azaltılabilir sorusu da bu alanda çalışma yapanların sorması gereken önemi sorulardan biridir. Araştırmalarden elde edilecek sonuçlar, toplumsal düzeyde birtakım kampanyaların düzenlenmesine ya da çeşitli eğitim seminerleriyle farkındalığın arttırılmasına ve bu yolla da suç korkusunun azaltılmasına katkı sağlayabilir. Bu kampanya ve semirlerde kişinin mevcut tehdidi, riski ve kendi başetme kapasitesinin yeniden değerlendirmesi üzerinde durulabilir (Halperin, 2006). Bu yolla, suçla ilgili yanlış inançlara ve suçun abartılı algılanan olasılığına karşı algılar değiştirilebilir. Ancak bu kampayaların içeriğinin suç korkusunu azaltmak yerine arttırmamasına dikkat edilmelidir. Çünkü, insanların suç oranları hakkında ve suçtan korunmak üzere etkili davranışlar edinme konusunda bilgilendirilmeleri "öz-yeterlik inançlarını" arttırabilecekleri düşünülse de (Chataway ve Hart, 2016), bazen insanların mağdur olma konusundaki endişelerini de tetikleyebilir (Bowers ve Johnson, 2003; Homel, Nutley, Webb ve Tilley, 2004).

Suç korkusunun azalması ve böylelikle de insanların toplumsal yaşam içinde daha özgür hareket edebilmeleri toplumsal refah açısından büyük önem taşımaktadır. Sonuçları uzun vadede elde edilecek olsa da suç korkusuna neden olan faktörleri göz önünde bulundurarak bazı önerilerde bulunmak mümkün görünmektedir. Yürütülen görgül çalışmalar suç korkusu ile tutarlı biçimde ilişkili olan birtakım faktörlerin ortaya konmasını sağlamıştır. Bunlardan belki de en önemlisi cinsiyetler arasındaki farklılıktır. Kadınların erkeklerden daha yüksek suç korkusuna sahip olduğunu ortaya koyan çok sayıda araştırma göz önünde bulundurulduğunda, bu farkın toplumsal cinsiyet rolleriyle ilişkili olabileceği akla gelmektedir. Geleneksel toplumsal cinsiyet normlarının çoğunlukla erkekleri daha özgüvenli, kadınları ise daha narin olmaya yönlendirdiği ve yine çoğunlukla suçla bağlantılı olan saldırgan davranışlar konusunda da erkekleri kadınlardan daha fazla teşvik ettiği ileri sürülebilir. Suçun özel bir türü olan kadına yönelik şiddet de kaynağını eşit olmayan güç ilişkilerini ortaya çıkaran toplumsal cinsiyet rollerinden almaktadır. Bu nedenle de kadınların yaşadıkları suç korkusunun azalmasında etkili olabilecek en önemli etkenlerden biri toplumsal cinsiyet eşitliğini arttıracak politikalar geliştirilmesidir. 
İlgili literatürdeki araştırmalarda dikkati çeken bir diğer önemli etken ise bireyin içinde yaşadığı sosyal çevre ve mahalledeki çevre düzensizliğidir (Marzbali, Abdullar, Razak ve Tilaki, 2012; Perkins ve Taylor, 1996). Bu nedenle de yerel yönetimlerin ve hükümetlerin bu konuda alabileceği bazı önlemlerin ve hayata geçirilecek özgül politikaların insanların suç korkusu deneyimlerini azaltabileceği düşünülmektedir. Özellikle suçu önleyici çalışmalar kapsamında kolluk kuvvetleri ile toplum arasında işbirliğini arttırmaya yönelik düzenlemeler yapılması uzun vadede insanlardaki suç korkusunu azaltabilecek önemli bir etken olarak değerlendirilebilir. Kitle iletişim araçlarındaki temsillerin de insanların suç korkusunu arttırdığı görgül çalışmalar ile ortaya konulmuş olup, kitle iletişim araçlarının insanlarda korkuyu tetikleyecek bir habercilik anlayışından uzak ve yayınlarını etik ilkeleri ve toplumsal refahı gözeterek yapmaları alınabilecek önlemler arasındadır.

Sonuç olarak, suç korkusu kişisel, kişiler arası ve gruplar arası düzeyde yaşamı etkileyen önemli bir toplumsal sorundur. Söz konusu kavrama ilişkin daha derin bir bakış açısı kazanmada psikolojinin farklı alt alanlarının ve özellikle de sosyal psikolojinin sunacağı büyük katkılar olduğuna inanmaktayız. Söz konusu katkıların suç korkusunu azaltmak için pratik doğurguları olacaktır.

\section{Kaynaklar}

Addington, L. A. (2003). Students' fear after Columbine: Findings from a randomized experiment. Journal of Quantitative Criminology, 19, 367-387.

Baumer, T. L. (1978). Research on fear of crime in the United States. Victimology, 3, 254-264.

Clark, J. (2003). "Fear in fear-of-crime". Psychiatry, Psychology and Law, 102, 267 282.

Cohen-Louck, K. ve Ben-David, S. (2017). Coping with terrorism: Coping types and effectiveness. International Journal of Stress Management, 24(1), 1-17.

Covington, J. ve Taylor, R. B. (1991). Fear of crime in urban residential neighborhoods: Implications of between-and-within neighborhood sources for current models. Sociological Quarterly, 32, 231-249.

Dobbs, R. R., Waid, C. A. ve Shelley, T. O. (2009). Explaining fear of crime as fear of rape among college females: An examination of multiple campuses in the United States. International Journal of Social Inquiry, 2, 105-122.

Doran, B. J. ve Burgess, M. B. (2012). Putting fear of crime on the map. London, UK: Springer. 
Duckitt, J. ve Fisher, K. (2003). The impact of social threat on worldview and ideological attitudes. Political Psychology, 24, 199-222.

Eitle, D. ve Taylor, J. (2008). Are Hispanics the new 'Threat'? Minority group threat and fear of crime in Miami-Dade country. Social Science Research, 37, $1102-1115$.

Erskine, H. (1974). The polls: Fear of violence and crime. Public Opinion Quarterly, 38, 131-145.

Farrall, S., Bannister, J., Ditton, J. ve Gilchrist, E. (1997). Questioning the measurement of the fear of crime: Findings form major methodological study. British Journal of Criminology, 34, 658-679.

Farrall, S., Gray, E. ve Jackson, J. (2007). Theorising the fear of crime: The cultural and social significance of insecurities about crime. Experience and Expression of fear of Crime, Working Paper,5.http://papers.ssrn.com/sol3/papers.cfm?abstract_id=1012393.

Ferraro, K. F. (1995). Fear of crime: Interpreting victimization risk. New York: State University of New York Press.

Ferraro, K. F. ve LaGrange, R. (1987). The measurement of fear of crime. Sociological Inquiry, 57, 70-90.

Fisher, S., Allan, A. ve Allan, M., M. (2004). Exploratory study to examine the impact of television reports of prison escapes on fear of crime, opertionalised as a state anxiety. Australian Journal of Psychology, 56, 181-190.

Fishman, G. ve Mesch, G. S. (1996). Fear of crime in Israel: A multidimensional approach. Social Science Quarterly, 77, 76-89.

Franklin, C. A. ve Franklin, T. W. (2009). Predicting fear of crime: Considering differences across gender. Feminist Criminology, 4, 83-106.

Franklin, T. W., Franklin, C. A. ve Fearn, N. E. (2008). A multilevel analysis of the vulnerability, disorder, and social integration models of fear of crime. Social Justice Research, 21, 204-227.

Furstenberg, F. F., Jr. (1971). Public reaction to crime in the streets. The American Scholar, 40, 601-610.

Gibson, C. L., Zhao, J., Lovrich, N. P. ve Gafney. M. J. (2002). Social integration, individual perceptions of collective efficacy, and fear of crime in three cities. Justice Quarterly, 19, 537-564.

Halperin, E. (2016). Emotions in conflict: Inhibitors and facilitators of peace making. New York: Routledge. 
Henson, B. (2011). Fear of crime online: Examining the effects of online victimization and perceived risk on fear of cyberstalking victimization. Doctoral dissertation, University of Cincinnati, Cincinnati, $\mathrm{OH}$.

Hough, N. (1995). Anxiety about crime: Findings from the 1994 British Crime Survey. Research findings N0: 25, Homo office Research and Statistics Department. London: Home Office. http://rds.homeoffice.gov.uk/rds/pdfs2/r25.pdf.

Jackson, J. ve Stafford, M. (2009). Public health and fear of crime: A prospect cohort study. British Journal of Criminology, 49, 832-847.

Jaycox, V. (1978). The elderly's fear of crime: Rational or irrational, Victimology, 3, 329-334.

Jost, J. T., Glaser, J., Kruglanski, A. W. ve Sulloway, F. J. (2003). Political conservatism as motivated social cognition, Psychological Bulletin, 129, 339-375.

Karakus, O., McGarrell, E. F. ve Basibuyuk, O. (2010). Fear of crime among citizens of Turkey. Journal of Criminal Justice, 38, 174-184.

Keane, C. (1992). Fear of crime in Canada: an examination of concentrate and formless fear of victimization. Canadian Journal of Criminology, 34, 215224.

Keane, C. (1998). Evaluating the infleunce of fear of crime as an emvironmental mobility restrictor on women's routibe activities. Environment and Behavior, 30, 60-74.

LaGrange, R. L., Ferraro, K. F. ve Suspancic, M. (1992). Perceived risk and fear of crime: Role of social and physical incivilities. Journal of Research in Crime and Delinquency, 29, 311-334.

Liska, A. E., Sanchirico, A. ve Reed, M. D. (1988). Fear of crime and constrained behavior: Specifying and estimating a reciprocal effects model. Social Forces, 66, 827-837.

Marshall, R. D., Bryant, R. A., Amsel, L., Suh, E. J., Cook, J. M. ve Neria, Y. (2007). The psychology of ongoing threat: relative risk appraisal, the September 11 attacks, and terrorism-related fears. American Psychologist, 62, 304-316.

May, D. C., Herbert, J., Cline, K. ve Nellis, A. (2011). Predictors of fear and risk of terrorism in a rural state. Internationa Journal of Rural Criminology, 1, 122. 
McGarrell, E., Giacomazzi, A. L. ve Thurman, Q. C. (1997). Neighborhood disorder, integration, and the fear of crime. Justice Quarterly, 14, 479-500.

Oh, H. J. ve Kim, S. (2008). Aging, neighborhood attachment, and fear of crime: Testing reciprocal effects. Journal of Community Psychology, 37, 21-40.

Öhman, A. (1993). Fear and anxiety as emotional phenomena: Clinical phenomenology evolutionary perspectives, and information-processing mechanisms. M. Lewis ve J. M. Haviland (Ed.), Handbook of emotions (511-536). New York, NY: Guilford

Pain, R. (2000). Place, social relations and the fear of crime: A review. Progress in Human Geography, 24, 365-387.

Pantazis, C. (2000). Fear of crime, vulnerability and poverty. The British Journal of Criminology, 40, 414-436.

Parker, K. D. (1988). Black-White differences in perceptions of fear of crime. The Journal of Social Psychology, 128, 487-494.

Phelan, J. E., Sanchez, D. T. ve Broccoli, T. L.(2010). The danger in sexism: The links among fear of crime, benevolent sexism, and well-being. Sex Roles, $62,35-47$.

Rachman, S. J. (1978). Fear and courage. San Francisco, CA: Freeman.

Rader, N. E. (2004). The threat of victimization: A theoretical reconceptualization of fear of crime. Sociological Spectrum, 24, 689-704.

Rader, N. E. (2010). Until death to us part? Husband perceptions and responses to fear of crime. Deviant Behavior, 31, 33-59.

Ratcliffe, J. H., Taniguchi, T., Groff, E. R. ve Wood, J. D. (2011). The Philadelphia foot patrol experiment: a randomized controlled trial of police patrol effectiveness in violent crime hotspots. Criminology, 49, 795-831.

Reese, B. (2009). Determinants of the fear of crime. International Journal of Sociology, 39, 62-75.

Roseman, I. J., Wiest, C. ve Swartz, T. S. (1994). Phenomenology, behaviors, and goals differentiate discrete emotions. Journal of Personality and Social Psychology, 67, 206-221.

Schafer, J. A., Huebner, B. M. ve Bynum, T. S. (2006). Fear of crime and criminal victimizations: Gender-based contrasts. Journal of Criminal Justice, 34, 285-301.

Spelman, W. (2004). Optimal targeting of incivility-reduction strategies. Journal of Quantitative Criminology, 20, 63-88. 
Taylor, J., Eitle, D. ve Russell, D. (2009). Racial/ethnic variation in the relationship between physical limitation and fear of crime: An examination of mediating and moderating factors. Deviant Behavior, 30, 144-174.

Taylor, R. B. ve Hale, M. (1986). Testing alternative models of fear of crime. Journal of Criminal Law and Criminology, 77, 151-189.

Van Dijk,, J., Van Kesteren, J. ve Smit, P. (2007). Criminal victimization in international perspective: Key findings from the 2004-2005 ICVS and EU ICS. http://rechten.uvt.nl/icvs/pdffiles/ICVS2004_05.pdf.

Warr, M. (1984). Fear of victimization: Why are women and elderly more afraid? Social Science Quarterly, 65, 681-702.

Warr, M. (1992). Alturistic fear of victimization in households. Social Science Quarterly, 73, 723-736.

Warr, M. (2000). Fear of crime in the United States: Avenues for research and policy. Criminal Justice, 4, 452-489.

Warr, M. ve Ellison, C. G. (2000). Rethinking social reactions to crime: Personal and altruistic fear in family households. American Journal of Sociology, 106, 551-578.

Williams, F. P., McShane, M. D. ve Akers, R. L. (2000). Worry about victimization: An alternative and reliable measure for fear of crime. Western Criminology Review, 2, 1-26. 